\title{
Communique Issued at the End of the First International Conference on Community, Trade and Religion in Coastal Yorubaland and Western Niger Delta, Held at Adeyemi College of Education, Ondo, from 6-8 December 2016
}

An international conference was held from December 6 to 82016 at Adeyemi College of Education Ondo, with the theme "Mobile Populations, Fluid Boundaries: Community, Trade and Religion in Coastal Yorubaland and the Western Niger Delta." The conference was sponsored by the European Research Council (ERC), and jointly organized by the University of Birmingham, Osun State University, and Adeyemi College of Education.

Over a period of three days, many papers were presented, covering various topics and issues on mythologies, oral traditions, religion, making sense of the Yoruba littoral, economy and intergroup relations in the Gulf of Guinea during the 18th and 19th centuries, trade on the north eastern bank of the Lagos lagoon, history, religion and community formation, moral traditions of the Yoruba and non-Yoruba speaking groups, and many more.

Arising from the papers presented, conference participants wish to communicate to the public and the government of Nigeria as follows:

\section{Adeyemi College of Education and Global Partnering}

Conference participants celebrate the achievements of Adeyemi College of Education in hosting this international conference. The facilities in the College are adequate and capable of hosting bigger conferences in future years. We recommend similar international collaborations to those that made this conference possible - an approach that we recommend to all Nigerian tertiary institutions.

\section{New Scholarly Approaches}

Conference participants celebrate the expansion of new frontiers of knowledge in Yoruba and coastal historiography and the rise of a new generation 
of scholars who also presented papers at the conference. We recommend support for this new generation of scholars so that they can continue to produce innovative scholarship. Such scholarly efforts must be accompanied by teaching, and the designing of a curriculum for courses relating to the peoples and cultures of coastal Yorubaland and the Delta. Tertiary institutions are called upon to study this region by encouraging fieldwork, research and publications.

\section{Popular Culture and Tourism}

Participants note the distinctive forms of religious practices, mythologies and other resources that abound in coastal Yorubaland and the western Niger Delta. The conference calls for concerted efforts towards making these more visible while equally connecting them to the economic activities in the region.

\section{Coastal Relevance}

Conference participants acknowledge the unique environment of coastal areas and the distinctive nature of marine life. We emphasise the centrality of the coast and its strategic nature, and the particular importance of lagoon and coastal markets to trade and economic history of Yorubaland, the western Delta, and beyond. We call for a focus on the changing role of seaports that considers the design and building of new ports as part of overall development thinking.

\section{Environmental Protection}

We note the debilitating effects of oil exploitation on the ecosystem of coastal Yorubaland and the western Niger Delta. We observed the changing nature of encounters and relationships between humans and the landscape over time, and the impact of the oil industry (and its industrial accidents) on the livelihoods of the people. There is a need for greater investments, ideally by government, in pathways to environmentally sustainable livelihoods for coastal people.

\section{Development and Living Standards}

Conference participants note the low level of socio-economic development in the coastal communities. The slow rate of development is traced to a long history of neglect, which contrasts with the region's economic importance. Conference participants observe that in many parts of this strategic region, the ruins of modernity are everywhere to see. The conference therefore calls on government to implement a development programme that recognizes the need for economic uplift, educational transformation, infrastructural development, and job creation. Conference participants also call for the enhancement of the capacity of fishermen to engage in commercial exploita- 
tion of marine resources such as crustaceans, which have the capacity to boost the total earnings from fishing.

\section{Conflict Reduction Strategies}

Conference participants observe the high incidence of violent conflicts that are related to identity contestations in coastal communities. As the high mobility in coastal areas means that coastal settlements are usually mixed and often multi-ethnic, we call for inclusive policies that enable members of heterogeneous communities to live in harmony.

\section{Accurate Mapping and Representation}

Conference participants note that there are many coastal communities that are not represented in official maps. This has affected development efforts in most of these communities. We recommended that proper mapping and representation are necessary to address developmental challenge in these communities.

\section{Conclusion}

The international conference on "Community, Trade and Religion in coastal Yorubaland and the western Niger Delta" urges the Nigerian government, the coastal states, international agencies and development partners to commence on a series of development processes aimed at rapid socioeconomic transformation of coastal Yorubaland and the western Niger Delta.

Motion for the adoption of the communiqué was moved by Prof Gboyega Ajayi and seconded by Dr Mobolaji Ajibade.

Issued 8th December 2016

Signed:

1. Toyin Falola, Jacob \& Frances Sanger Mossiker Chair in Humanities, Department of History, University of Texas at Austin, USA.

2. Insa Nolte, President, African Studies Association of the UK and Reader, Department of African Studies and Anthropology, University of Birmingham, UK.

3. Olukoya Ogen, Provost and Professor of History, Adeyemi College of Education, Ondo, Nigeria. 